\title{
THE DEBTOR'S PROPERTY SELLING IN THE CROSS-BORDER INSOLVENCY PROCEEDINGS
}

\author{
Daiga Sproge
}

\author{
Turiba University,Latvia, sproge@latlaw.lv
}

\begin{abstract}
The title of this research is "The debtor's property selling in the cross-border insolvency proceedings". The insolvency proceeding gets the cross-border status also in case, if a debtor is an owner of the property outside of the main interests' centre, namely, in another country. Therefore, there are many problematic cases when insolvency administrator (also called insolvency practitioner) defines the real estate in this other country and has to make a decision concerning the methods of selling the real estate in accordance with the law of the Member State in which territory the insolvency proceedings have been started. At the same time, the administrator shall provide that the property is sold in particular with regard to procedures for the realization of assets defined in the legislation of that country, where such real estate has been located. The article's aim is to give a view of the features of the sale of the property in the insolvency proceedings and to define the possible lack and improvements in the cross-border insolvency concerning the selling of a debtor's property. The European Parliament and the Council of the European Union has adopted Regulation (EU) 2015/848 of 20 May 2015 on Insolvency proceedings, which shall apply from 26 June 2017, with some exceptions Despite the regulation of the cross-border insolvency has been improved, the procedure of the property disposal is still incomplete in the cross-border insolvency proceedings. Within the study the following research methods are applied: the analytical method, comparative method, sociological method and descriptive method. The predicted value of the research is theoretical and also practical. The research should be useful for the insolvency proceedings administrators, the companies and the banks, other experts involved in the cross-border insolvency proceedings, as well as for students to improve their theoretical knowledge about the cross-border insolvency
\end{abstract}

Keywords: Law; cross-border insolvency proceedings; property, auction.

Type of the paper: Theoretical paper

JEL Classification: K330

\section{Introduction}

"If international economic law is not necessarily congruent with the laws of international economics, it is nevertheless true that economics - knowledge, faith, skepticism included - has had a strong influence on the shape and evolution of the international trade, investment, and financial transactions" (Lowenfeld, 2003:4)

In nowadays the cross-border activities are those taking place when a company is running business in more than one Member State of the European Union. For example, when the registered office and the headquarters of the company are located in Latvia, however, an affiliate or another office is located in Estonia. In these cases, therefore it is necessary to avoid incentives of the companies, upon becoming insolvent, for example, to transfer assets from one Member State to another seeking to obtain a beneficial legal position in administration of insolvency proceedings, and this may not always suit the creditors' interests.

"The proper functioning of the internal market requires that cross-border insolvency proceedings should operate efficiently and effectively" (Proposal for a Regulation, 2012:2). These objectives were not possible to achieve to a sufficient degree on the national level, and here the necessity arouse to improve the effectiveness of cross-border insolvency proceedings by means of drawing up standard provisions regarding recognition of judgments and application of laws and regulations, to be incorporated in a single Community act, which then become directly applicable in Member States.

As result, "the Council Regulation (EC) No 1346/2000 of 29 May 2000 on Insolvency Proceedings" 
(hereinafter - Regulation No 1346/2000) was drawn up which for the first time laid down obligatory basic cooperation requirements "between the Member states of the European Union in regard to crossborder insolvency proceedings" (Regulation No 1346/2000, 2002). Regulation No 1346/2000 entered into force on the $31^{\text {st }}$ of May 2002, in Latvia - on $1^{\text {st }}$ May 2004, and is applicable to all Member States of the European Union (except Denmark).

Regulation No 1346/2000 "should apply to any insolvency proceedings, whether the debtor is a natural or legal person, a company or an individual." Before the Regulation No 1346/2000 become effective, the judgments of the Member States' courts on insolvency proceedings become effective only in the States where the particular judgments were made, and quite so often they failed to prevent from repeating similar cases of individual debt recovery in other Member States. "The provisions of the Regulation No 1346/2000, however, resulted in a substantial improvement in this field" (Regulation No 1346/2000, 2002; Saleniece, Upenieks, 2007:3).

The Regulation No 1346/2000 has changed cross-border insolvency law in Europe more than all the treaties, case law and academic writings in innumerable decades previously. As a consequence, the enactment of this measure of European law has attracted global interest and all of a sudden the developments, interpretations and application of its rules became a trend-setter in this field of law for the rest of the world. This stands in stark contrast to the times before when cross-border insolvency situations in Europe were observed and commented on, if at all, only occasionally and within small groups of insiders with rarely any impact or influence on other jurisdictions (Moss et al. 2009:28).

While the Regulation No 1346/2000 "is generally considered to operate successfully in facilitating cross-border insolvency proceedings within the European Union, the consultation of stakeholders and legal and empirical studies commissioned by the Commission revealed a range of problems in the application of the Regulation in practice. Moreover, Regulation No 1346/2000 does not sufficiently reflect current EU priorities and national practices in insolvency law, in particular in promoting the rescue of enterprises in difficulties. The overall objective of the revision of Regulation No 1346/2000 is to improve the efficiency of the European framework for resolving cross-border insolvency cases in view of ensuring a smooth functioning of the internal market and its resilience in economic crises. This objective links in with the EU's current political priorities to promote economic recovery and sustainable growth, a higher investment rate and the preservation of employment, as set out in the Europe 2020 strategy" (Proposal for a Regulation, 2012:3).

Therefore, "the European Parliament and the Council of the European Union, having regard to the proposal from the European Commission, have adopted Regulation (EU) 2015/848 of 20 May 2015 on Insolvency proceedings" (hereinafter - Regulation No 2015/848). "The provisions of Regulation No 2015/848 shall apply only to insolvency proceedings opened after 26 June 2017." (Regulation No 2015/848, 2015:92).

At the same time, there are several exceptions concerning the few articles entering into force, for example, Article 86, which shall apply from 26 June 2016, determines that the "Member States shall provide, within the framework of the European Judicial Network in civil and commercial matters and with a view to making the information available to the public, a short description of their national legislation and procedures relating to insolvency. The Article 24(1), which shall apply from 26 June 2018, provides that Member States shall establish and maintain in their territory one or several registers in which information concerning insolvency proceedings is published ('insolvency registers'). That information shall be published as soon as possible after the opening of such proceedings" (Regulation No 2015/848, 2015:92).

"Acts committed by a debtor before that date shall continue to be governed by the law which was applicable to them at the time they were committed. Notwithstanding Article 91 of Regulation No 2015/848, Regulation No 1346/2000 shall continue to apply to insolvency proceedings which fall within the scope of that Regulation No 2015/848 and which have been opened before 26 June 2017" (Regulation No 2015/848, 2015:84).

The Research's aim is to give a view of the features of the sale of the property and to define the possible lack and improvements in the cross-border insolvency. 
To achieve the above mentioned aim, the author will focus on the cross-border legal regulation, analyse the issues of auction of the debtor' property in the national and cross-border insolvency regulation, and define the lack and possible improvements of the cross-border regulation. Within the study the following research methods are applied: the analytical method, comparative method, sociological method and descriptive method.

\section{The Concept of the Cross-border Insolvency}

To understand the "cross-border insolvency proceedings, it would be necessary to start with the insolvency proceedings. Usually, there are two types of the insolvency proceedings - voluntary and involuntary insolvency" (Garner, 2001:60), where voluntary insolvency is a bankruptcy proceeding initiated by the debtor, and involuntary insolvency is a bankruptcy proceeding initiated by the creditor to force the debtor to declare bankruptcy or be legally declared bankrupt (Garner, 2001:60).

In the United States very popular is insolvency reorganization before the winding-up procedure. A fraudulent conveyance occurs when a debtor conveys or transfer funds or assets for the purpose of defrauding its creditors. The third party that receives the funds or assets from the debtor typically provides little or no consideration in return. Both the Bankruptcy Code and state law invalidate these conveyances or transfers (Haas, 2004:260).

A fundamental issue in international insolvency law is whether the effects of an insolvency proceeding are to be universal (Viimsalu, 2009:32), i.e. in all countries where assets of the debtor are situated, or whether territoriality restricted "insolvency proceedings may be opened in each country" (Virgós, Garcimartín, 2014:11). The "rules of jurisdiction set out in the Regulation No 1346/2000 establish only international jurisdiction" (Torremans, 2002:157) to open insolvency proceedings. Article 3 of the Regulation No 1346/2000 regulates the relationship between main and territorial insolvency proceedings and the requirements pursuant to which they may be opened (Torremans, 2002:157).

For example, in Latvia, the "insolvency proceedings of a legal person are an aggregate of measures of a legal nature, within the scope of which the claims of creditors are settled from the property of a debtor, in order to promote the honoring of the debtor's obligations. The insolvency proceedings of a legal person can be voluntary and involuntary insolvency proceeding. While the insolvency proceedings of a natural person are an aggregate of measures of a legal nature whose aim is to satisfy the claims of creditors as much as possible from the property of a debtor and provide the opportunity for a debtor whose property and income is insufficient to cover the entire obligations to be released from the obligations which have not been honored and to restore solvency" (Insolvency Law of the Republic of Latvia, 2010:4). In this case the insolvency proceedings of a natural person can be only voluntary insolvency proceeding.

The Regulation 1346/2000 stipulates that the "main insolvency proceedings shall be opened in the Member state where debtor's center of main interests is situated. Centre of main interest should correspond to a place where the debtor conducts the administration of his interests on regular basis and is therefore ascertainable by third persons. For natural persons their center of main interest normally should be their place of habitual residence" (Regulation No 1346/2000, 2002:13).

At the same time the "presumptions that the registered office, the principal place of business and the habitual residence are the center of main interests should be rebuttable, and the relevant court of a Member State should carefully assess whether the center of the debtor's main interests is genuinely located in that Member State. In the case of a company, it should be possible to rebut this presumption where the company's central administration is located in a Member State other than that of its registered office, and where a comprehensive assessment of all the relevant factors establishes, in a manner that is ascertainable by third parties, that the company's actual center of management and supervision and of the management of its interests is located in that other Member State" (Regulation 2015/848, 2015:30).

"In the case of an individual not exercising an independent business or professional activity, it should be possible to rebut this presumption, for example, where the major part of the debtor's assets is located outside the Member State of the debtor's habitual residence" (Regulation No 1346/2000, 
2002).

Although there is now a broad consensus at least in theory that the principle of universality is the better solution in a globalized world, because it also reduces the cost of the credit by allowing ex ante more efficient assignment of capital and reduces ex post the rush "by the creditors to request the opening of insolvency proceedings" (Virgós, Garcimartín, 2014:15). However, the universal model can be modified, for example, a) by allowing certain subordinated territorial insolvency proceedings to run concurrently alongside the main insolvency process; b) by allowing, under certain conditions, "the opening of territorial insolvency proceedings without the need to open proceedings with universal scope; or c) by establishing exceptions to the application of the lex fori concursus" (Virgós, Garcimartín, 2014:16). So, universal proceduralism, have been introduced (Janger, 2007:819).

Therefore, it is necessary to regulate such cross-border insolvency actions to achieve the balance between the claims of creditors and the selling of the property of a debtor.

\section{Main Insolvency Proceedings}

In general, the main insolvency proceedings are the most popular proceedings within the cross-border insolvency process. A number of legal issues, in addition to the national laws and regulations governing the opening of the proceedings, are governed by the Regulation 1346/2000 and from June 26 of 2017 the Regulation 2015/848, including the following:

- The duty to notify on individual basis the creditors of "other Member States on the opening of the main insolvency proceedings" (Regulation No 1346/2000, 2002);

- The authority of the creditors, whose "habitual residence, domicile or registered office is located in the territory of the European Union, to lodge claims" within the scope of the main insolvency proceedings and secondary insolvency proceedings (Regulation No 1346/2000, 2002; Saleniece, Upenieks, 2007:4);

- "When main insolvency proceedings are opened, the territorial insolvency proceedings shall become secondary insolvency proceedings" (Regulation 2015/848, 2015:3).

The main insolvency proceedings have the following effects:

- "Assets that are situated outside the territory of the State where the main insolvency proceedings were opened, except for the assets of secondary insolvency proceedings, are deemed to be a subject of this proceedings as from the date of opening thereof" (Dirix, Sagaert, 2006:59);

- The scope of the main insolvency proceedings includes all creditors, with the exception of secondary insolvency proceedings;

- An insolvency proceedings opened in one Member State shall have the same effects in all Member States. The recognition of the effects of insolvency proceedings in other Member States shall take place automatically and it will not be subject to formal procedure for recognition of judgments made by foreign institutions or previous notice. "In order for Regulation 2015/848 to apply, proceedings (comprising acts and formalities set down in law) should not only have to comply with the provisions of this Regulation, but they should also be officially recognized and legally effective in the Member State in which the insolvency proceedings are opened" (Regulation 2015/848, 2015). "This recognition includes the termination of the debtor's authority to dispose of the assets. It also puts an end to a judgment that results in executing in favor of an individual creditor" (Wessels, Omar, 2009:9);

- The liquidator of the "main insolvency proceedings shall be empowered to operate in other Member States of the European Union" as well (Regulation 1346/2000, 2002:36). "Such provision empowers any liquidator to participate in other proceedings. The aim of this provision is to better ensure the presence of creditors and the expression of their interests through the liquidator. In order to resolve the frequent absence of creditors, the provision allows the liquidator to attend creditors' meetings" (Wessels, Omar, 2009:34);

- "Prohibition to realize the existing debtor's assets on individual basis in other Member States of the European Union" (Regulation No 1346/2000, 2002; Saleniece, Upenieks, 2007:5). 
"In cases where the debtor's center of main interests is located in a Member State, the courts of other Member States have no power to open main insolvency proceedings. However, any of those States may open territorial proceedings, if the debtor has an 'establishment' in the territory of that State. This is called a secondary proceeding" (Wessels, Omar, 2009:37)

\section{Secondary Insolvency Proceedings}

"To protect the creditors interests, the Regulation 1346/2000 and Regulation 2015/848 allows Secondary insolvency proceedings to be opened in another Member State, which would run in parallel to the main insolvency proceedings. Their effects shall be restricted to the debtor's assets situated within the territory of that other Member State" (Regulation No 1346/2000, 2002; Regulation 2015/848, 2015; Saleniece, Upenieks, 2007:7).

The competent court of the Member State empowered to open secondary insolvency proceedings needs to examine "whether the court of another Member State, empowered to open main insolvency proceedings, opened insolvency proceedings within the meaning of Article 2 (a) of the Regulation $1346 / 2000$ as listed in Annex A of the Regulation 1346/2000 and whether its judgment is effective" (Regulation 1346/2000, 2002). In order to do that the competent court of the Member State which has jurisdiction "to open main insolvency proceedings has to clearly express in the judgment that it has jurisdiction within the meaning of Article 3 (1) of the Regulation 1346/2000, and that main insolvency proceedings listed in Annex A of the Regulation 1346/2000 have been opened" (Regulation 1346/2000, 2002).

Such a provision to express clearly what set of insolvency proceedings are "being opened by the competent court of Member State may be inserted into the national laws of the Member States" (Jakubecki A., 2013:241). "In order to state whether the judgment opening of insolvency proceedings concerns main or secondary insolvency proceedings, the national laws of the Member States should be amended accordingly, if the court has no legal grounds to clearly specify its international jurisdiction and type of the insolvency proceedings opened in a given case" (Viimsalu, 2009:39).

"According to the Virgós-Schmit Report the concept and definition of establishment was the subject of intensive debate from the very beginning of the territorial insolvency proceedings, because it is linked to the basis of international jurisdiction to open secondary insolvency proceedings" (Viimsalu, 2009:42).

Fletcher states that the key concept "in relation to the opening of secondary insolvency proceedings is the existence of an "establishment" belonging to the debtor" (Fletcher, 2005:375). Thus, what are the main problems which may be faced by the "courts of the Member States empowered to open secondary insolvency proceedings implementing the concept of establishment, which is according to Article 2 (h) of the Regulation 1346/2000 based on the following criteria: any place of operations, non-transitory nature of economic activity and utilization of human means and goods" (Viimsalu, 2009:46).

The stay of "secondary insolvency proceedings may be requested by the administrator in the main insolvency proceedings provided that it is in the capacity to take discharge the potential request of the court to take any suitable measures to guarantee the interests of the creditors in secondary insolvency proceedings" (Regulation 2015/848, 2015:37).

Such order has been defined in the Regulation 2015/848 "in order to avoid the opening of secondary insolvency proceedings. In Article 36 of the Regulation 2015/848 is noted that in order to avoid the opening of secondary insolvency proceedings, the insolvency practitioner in the main insolvency proceedings may give a unilateral undertaking (the 'undertaking') in respect of the assets located in the Member State in which secondary insolvency proceedings could be opened, that when distributing those assets or the proceeds received as a result of their realization, it will comply with the distribution and priority rights under national law that creditors would have if secondary insolvency proceedings were opened in that Member State" (Regulation 2015/848, 2015:36). 
The "undertaking shall specify the factual assumptions on which it is based, in particular in respect of the value of the assets located in the Member State concerned and the options available to realize such assets. The undertaking shall be made in writing and in the official language or one of the official languages of the Member State where secondary insolvency proceedings could have been opened, or, where there are several official languages in that Member State, the official language or one of the official languages of the place in which secondary insolvency proceedings could have been opened" (Stones, 2015; Regulation 2015/848, 2015:36).

The "undertaking shall be approved by the known local creditors. The rules on qualified majority and voting that apply to the adoption of restructuring plans under the law of the Member State where secondary insolvency proceedings could have been opened shall also apply to the approval of the undertaking. The insolvency practitioner shall inform the known local creditors of the undertaking, of the rules and procedures for its approval, and of the approval or rejection of the undertaking" (Regulation 2015/848, 2015:36).

It should be stressed that by its nature secondary insolvency proceedings are not a special type of proceedings. The Regulation 1346/2000 modifies conditions to open secondary insolvency proceedings laid down by the applicable national law in two aspects: the "requirement for the de facto insolvency of the debtor established by national law does not need to be satisfied; the recognition of the decision opening main insolvency proceedings makes any further examination of the debtor's insolvency in other Member States unnecessary; and the right to request the opening of secondary insolvency proceedings is vested directly to the liquidator of the main insolvency proceedings" (Regulation 1346/2000, 2002:27).

The court seized of a "request to open secondary insolvency proceedings shall immediately give notice to the insolvency practitioner or the debtor in possession in the main insolvency proceedings and give it an opportunity to be heard on the request. But here an undertaking has become binding in accordance with Article 36 of the Regulation 2015/848, the request for opening secondary insolvency proceedings shall be lodged within 30 days of having received notice of the approval of the undertaking" (Regulation 2015/848, 2015:38).

In general, due to the many consummates the Regulation 2015/848 improves the "efficiency of the European framework for resolving cross-border insolvency cases in view of ensuring a smooth functioning of the internal market and its resilience in economic crises" (Regulation 2015/848, 2015).

\section{The Debtor's Property Selling}

The purpose of the insolvency proceedings "is to promote the honoring of the obligations of a debtor in financial difficulties and, where possible, the renewal of solvency, applying the principles and lawful solutions specified in the Law. Hence, in the Member States the most important is to promote the honoring of the debtor's obligations from the property of a debtor" (Insolvency Law of the Republic of Latvia, 2010:1).

The property in the general comprehension "means any external thing over which the rights of possession, use, and enjoyment are exercised" (Garner, 2001:563). In Latvia Insolvency Law of the Republic of Latvia Article 93(1) provides that "within the meaning of this Law, the property of a debtor is the immovable property and moveable property of a debtor, including funds; funds acquired by alienating the property of a debtor; the property recovered in accordance with this Law; fruits that have been acquired from the property of the debtor during the insolvency proceedings of a legal person; and other property legally acquired during the insolvency proceedings of a legal person" (Insolvency Law of the Republic of Latvia, 2010:93).

Suppose, for example, that the debtor defaults on its obligation to repay interest. This will generally lead to an acceleration of the obligation to repay the principal amount. If the debt is secured by property, the insolvency administrator may then proceed to enforce the security interest - that is, to enforce the lien (Klein, Coffee, 2004:259). This would involve a procedure leading to the selling of the property to satisfy the claims of the bondholders. 
In Latvia it is necessary to apply to the insolvency proceedings the general principles, like, the "principle of the preservation of rights - the rights of creditors acquired prior to proceedings shall be observed during the proceedings; the principle of effectiveness of proceedings - such measures which allow the objective of the proceedings to be achieved in a most complete manner with the least resources shall be applicable within the scope of proceedings; the principle of quick turnover - the task of the proceedings is to maintain a commercially lawful quick turnover, the sale of the property of a debtor shall be performed in order to ensure the return thereof to commercially lawful circulation as quickly as possible; principle of transparency - in order to ensure credibility, information regarding proceedings must be accessible to all persons involved in the proceedings, thereby promoting the observation of the interests of these persons and the achievement of the objectives of the proceedings" (Insolvency Law of the Republic of Latvia, 2010:6).

Each Member State's normative acts intend different methods of "sale of the property of a debtor coordinated with the secured debtor - with or without an auction" (Insolvency Law of the Republic of Latvia, 2010:113). For example, Insolvency Law of the Republic of Latvia Article 113 defines that insolvency "administrator shall include the information in the plan for the sale of the debtor's property concerning the methods of sale of the non-pledged property of a debtor - with or without an auction" (Insolvency Law of the Republic of Latvia, 2010:113).

Similar situation is also in the Bankruptcy Act of the Republic of Estonia where Article 136 provides that "bankruptcy estate is sold by auction pursuant to the procedure provided by the Code of Enforcement Procedure and the starting price of assets shall be determined by the trustee and approved by the bankruptcy committee" (Bankruptcy Act of the Republic of Estonia, 2004:136). Then Article 137 provides that a "general meeting of creditors may require the trustee by a precept to sell the assets without an auction if the sale of assets in another manner is more profitable" (Bankruptcy Act of the Republic of Estonia, 2004:137).

In Latvia Insolvency Law Article 115 provides that if "debtor's property is sold at auction, the auction thereof shall be carried out and the ownership rights recorded in the beneficiary's name in accordance with the provisions of the Civil Procedure Law regarding the sale of property in a compulsory auction, unless otherwise prescribed by this Law. Also, the sale of the property of the debtor serving as security (pledged property) shall take place in auctions in accordance with the procedure specified in the Civil Procedure Law, if the secured creditor has not agreed with the administrator on the sale of property without an auction. The administrator shall perform the activities of the bailiff specified in the Civil Procedure Law in respect of the auction of the debtor's property. By agreeing with the secured creditor on the sale of pledged property, the administrator shall ensure that this property is sold for as high a price as possible, taking into account the interests of non-secured creditors" (Insolvency Law of the Republic of Latvia, 2010:115).

In Estonia the Bankruptcy Act Article 139 provides "if a trustee sells an immovable included in the bankruptcy estate at an auction, only such rights encumbering the immovable which have a ranking higher than the right which was entered first in the land register and according to which forced sale of the immovable may be demanded remain in force. The rest of the rights encumbering the immovable which are entered in the land register are deemed to have extinguished. The rights entered in the land register which have the same ranking as the right which was entered first in the land register and according to which forced sale of the immovable may be demanded remain in force only if forced sale of the immovable cannot be demanded according to such rights" (Bankruptcy Act of the Republic of Estonia, 2004:139).

In the local insolvency proceedings in general there are no difficulties in the selling procedure of the debtor's property. The problems arise at the moment when insolvency proceedings administrator establishes the property in the different Member State and they are mostly related to the selling procedure due to the law of the Member State where the immovable property is located.

The frontal problem is the lack of the information; therefore, insolvency practitioner does not get the information about possible property in different Member States or outside the European Union. 


\section{The Property Selling Lack in the Cross-border Insolvency Proceedings}

"In nearly all the European Union Member States, contracts covering immovable property are subject of the special rules. This means that both on a level of conflict of laws as well as on the level of international jurisdiction, one has to take into account several interests. The main categories are the interests of the parties to the contract and the general interests protected by the State in which the immovable property is to be found. Protection of these specific interests were considered to justify an exception to the application of the law of the State of the opening of the proceeding. Therefore, Regulation 1346/2000 Article 8 makes the effects of the insolvency proceedings solely subject to the law of the Member State where the immovable property is located. The word 'solely' illustrates that only and exclusively the law of the Member State of the location of the immovable property (lex rei sitae), and not the lex concursus under Article 4, is applicable to establish these effects." (Wessels, 2006:21)

In practice insolvency administrators face several problems during the selling process of the immoveable property, which is located in another Member State.

The Article 4(1) of the Regulation 1346/2000 defines that "save as otherwise provided in that Regulation, the law applicable to insolvency proceedings and their effects shall be that of the Member State within the territory of which such proceedings are opened. Then, the Article 18 (3) regulates that in exercising his powers, the liquidator shall comply with the law of the Member State within the territory of which he intends to take action, in particular with regard to procedures for the realization of assets. Those powers may not include coercive measures or the right to rule on legal proceedings or disputes" (Regulation 1346/2000, 2002: 4,18).

Similar regulation is in the Regulation 2015/848 and its Article 21 provides that in "exercising its powers, the insolvency practitioner shall comply with the law of the Member State within the territory of which it intends to take action, in particular with regard to procedures for the realization of assets. Those powers may not include coercive measures, unless ordered by a court of that Member State, or the right to rule on legal proceedings or disputes" (Regulation 2015/848, 2015:21).

The terminology "shall comply" in English appears to be stricter than various other text, see the Netherlands "eebiedigen", french: "doit respecter", which is the equivalent of "to respect". Therefore, the "principle of the lex concursus of main insolvency proceedings stays intact, with due respect to the lex fori of the other Member State, in as far as it concerns taking actions, more specifically procedures for the realization of assets" (Wessels, 2012:681).

The lex concursus establishes the "extent of the powers of the insolvency administrator and the manner in which such powers may be exercised. Only the lex fori concursus of the main proceedings is decisive with regards to, for example, whether the sale of immoveable property can be a private market transaction or if a sale by public auction is necessary. Once the lex concursus has determined the form of sale, the procedures by which the assets are realized must be in accordance with the provisions of the national law of approached Member State. If the lex concursus requires a sale by public auction, the procedure for carrying out this sale in the State where the immoveable property is situated shall therefore be determined by the Law of that latter State" (Verweij, Wessels B., 2010:186).

Not clear is the situation when in the main proceedings State, the immoveable property is possible to be sold only on the public auction. So far, it should be clear that insolvency administrator makes a decision to sell the property at an auction. According to the "principle lex concursus, which determines the form of sale" (Verweij, Wessels B., 2010:186), insolvency administrator should realize selling procedure in accordance with the provisions of the national law of approached Member State, where the property is located. Then insolvency administrator finds out that in this Member State it is possible to "sell the property at an auction" (Insolvency Law of the Republic of Latvia, 2010:113), but the problem is that such auction can be organized only through special electronic means and only local insolvency administrators have an access to such auction system. Therefore, insolvency administrator concludes that he/she cannot register to obtain access to the electronic auction system and sell the property like the main proceedings insolvency administrator. 
Such situation is unacceptable, because Regulation defines that the "insolvency practitioner appointed by a court which has jurisdiction pursuant to Article 3(1) may exercise all the powers conferred on it, by the law of the State of the opening of proceedings; the insolvency practitioner may, in particular, remove the debtor's assets from the territory of the Member State in which they are situated" (Regulation 1346/2000, 2002:21).

The author supposes that to resolve the mentioned problem it would be necessary to provide that all property selling procedures by public auction should be organized by using electronic means within the European Union. Such electronic auction system is already applicable in Latvia (insolvency administrators sell debtor's property in the electronic auction site $-\underline{\text { www.izoles.ta.gov.lv since } 1^{\text {st }}}$ January of 2016), besides similar procedure is in Estonia, Lithuania, Hungary and Czech Republic (Kirsons, 2015).

The electronic auctions are created to prevent problems in the field of auction relating to its participants' interpersonal possibility of reducing the person dishonest or unlawful conduct of the feasibility of real estate auctions. In addition, it is contemplated that the electronic auction makes more comfortable and more economical auction process, thereby it is possible to recover a larger amount of means to cover creditors' claims (The Cabinet Republic of Latvia 16.06.2015. "Rules of electronic auctions site" No 318).

So, if each Member State provides that the public auctions are organized by official electronic site, then it would be useful and effective to unify electronic auction sites. Thus, it would be possible to organize the "interconnection of such electronic auction registers via the European e-Justice Portal" (Proposal for a Regulation, 2012).

Regulation 1346/2000 and Regulation 2015/848 provide that "where the center of the debtor's main interests is situated within the territory of a Member State, the courts of another Member State shall have jurisdiction to open insolvency proceedings against that debtor only if it possesses an establishment within the territory of that other Member State. The effects of those proceedings shall be restricted to the assets of the debtor situated in the territory of the latter Member State" (Regulation 1346/2000, 2002; Regulation 2015/848, 2015).

The author supposes that another solution to the problem that insolvency administrators cannot or it is difficult to sell the immoveable property, which is located in another Member State, would be to permit to open the secondary proceedings at the Member State, where property is located, without any requirement for establishment within the territory of that Member State.

Therefore, it is necessary to consummate the Regulation 2015/848 Article 3 (2) and provide that "where the center of the debtor's main interests is situated within the territory of a Member State, the courts of another Member State shall have jurisdiction to open insolvency proceedings against that debtor only if it possesses an establishment within the territory of that other Member State. The effects of those proceedings shall be restricted to the assets of the debtor situated in the territory of the latter Member State" (Regulation 2015/848, 2015:3). In case it is impossible or too complicated to sell the immoveable property, which is located in another Member State, the courts can open the secondary insolvency proceedings.

\section{The Transparency of Cross-border Insolvency Procedures}

One of the problems "concerning the procedural framework for determining jurisdiction" (Proposal for a Regulation, 2012) is lack of information about the possible property in the other Member States or somewhere else. At this moment insolvency administrator can find the information about debtor's property in the local public registers. Not always the representative of a debtor performs duties in good faith.

In Latvia "the representative of a debtor has the duty to provide the information requested by the court or administrator regarding the debtor without delay, but not later than within 10 days following the day of sending the request, besides the representative of the debtor shall submit the requested information or the appropriate notification that he or she is unable to submit in writing the information requested, certifying this with his or her signature" (Insolvency Law of the Republic of Latvia, 
2010:71).

In case the representative of a debtor does not perform duties in good faith and does not submit information requested by insolvency administrator, it is complicated to establish the debtor's property in the other Member State.

In Latvia since $1^{\text {st }}$ March of 2015 is in force Article $72^{1}$ of Insolvency Law which provides the liability of the representative of a debtor. The mentioned Article provides that Members of the Board of a debtor jointly liable for the damages, if they do not transfer requested information, like, debtor's accounting documents, or such documents are in a very bad condition, therefore insolvency administrator cannot evaluate the financial situation over the past three years prior to the insolvency proceedings. The amount of mentioned damages is presumed as the claims of creditors amount in general, which is not possible to cover during the debtor's insolvency proceedings. The insolvency administrator prepares and submits such claim to the court (Insolvency Law of the Republic of Latvia, 2010:72 ${ }^{1}$ ). Despite the amendments in Insolvency Law, in Latvia there is still a problem that insolvency administrator is not able to get all the information about debtor's property.

Significantly, that Regulation 2015/848 provides innovation concerning the transparency of crossborder insolvency procedures. The "certain minimum information relating to the insolvency proceedings has to be published in an electronic register available to the public free of charge via the internet" (Proposal for a Regulation, 2012: 6).

"In order to facilitate access to that information for creditors and courts domiciled or located in other Member States, this Regulation 2015/848 provides for the interconnection of such insolvency registers via the European e-Justice Portal. Member States will be free to publish relevant information in several registers and it will be possible to interconnect more than one register per Member State. Till 26 June of 2018 all Member States have to establish and maintain in their territory one or several registers in which information concerning insolvency proceedings is published ('insolvency registers'). That information shall be published as soon as possible after the opening of such proceedings" (Regulation 2015/848, 2015, 24).

Author thinks that very positive innovation in the Regulation is Article 86 providing that the Member States "organize within the framework of the European Judicial Network in civil and commercial matters and with a view to make the information available to the public, a short description of their national legislation and procedures relating to insolvency" (Regulation 2015/848, 2015:86). This provision will be in force from June 26 of 2016 and will help insolvency administrators to find out the necessary information about the debtor's property selling methods.

Author supposes that such innovation will improve and provide an effective administration of crossborder insolvency proceedings, also will "improve the effectiveness of the insolvency proceedings in cases where the debtor has an establishment in another Member State" (Proposal for a Regulation, 2012).

Unfortunately, such innovation does not resolve the lack of information about debtor's property, which is located in the other Member State. Therefore, author supposes that by analogy with the insolvency registers it should be necessary to include in the Regulation a provision ensuring that Land register offices or similar institutions in all Member states interconnect in one register that would be available to the insolvency administrators.

Such possibility to receive the information from the Land register offices is evaluated positive and will help insolvency administrators to achieve the purpose of the insolvency law and "promote the honouring of the obligations of a debtor in financial difficulties and, where possible, the renewal of solvency, and to renew the ability of a debtor to settle their debt obligations when a debtor has financial difficulties" (Insolvency Law of the Republic of Latvia, 2010:1).

\section{Conclusions}

European Parliament and the Council of the European Union, having regard to the proposal from the European Commission, have adopted Regulation (EU) 2015/848 of 20 May 2015 on Insolvency 
proceedings, which improves the "efficiency of the European framework for resolving cross-border insolvency cases in view of ensuring a smooth functioning of the internal market and its resilience in economic crises" (Regulation 2015/848, 2015).

Where local law provides for certain formal procedure for the realization of assets, the insolvency administrator shall comply with the law of the State in which the assets are located. The insolvency administrators exercising its powers, have problems to comply with the law of the Member State, where immovable property is located, because the "law applicable to insolvency proceedings of the Member State within the territory of which such proceedings are opened" (Regulation 2015/848, 2015).

The author supposes that to resolve the problem that insolvency administrators cannot or it is difficult to sell the immoveable property, which is located in another Member State, it would be necessary:

- $\quad$ to provide that within the European Union all property selling procedures by public auction should be organized by using electronic means. Thus, it would be possible to unify electronic auction sites and organize the "interconnection of such electronic auction registers via the European e-Justice Portal" (Proposal for a Regulation, 2012), or;

- to permit opening of the secondary proceedings at the Member State, where property is located, without any requirement for establishment within the territory of that Member State. Therefore, it would be useful to consummate the Regulation 2015/848 Article 3 (2) and provide that "where the center of the debtor's main interests is situated within the territory of a Member State, the courts of another Member State shall have jurisdiction to open insolvency proceedings against that debtor only if it possesses an establishment within the territory of that other Member State. The effects of those proceedings shall be restricted to the assets of the debtor situated in the territory of the latter Member State" (Regulation 2015/848, 2015:3). In case it is impossible or too complicated to sell the immoveable property, which is located in another Member State, the courts can open the secondary insolvency proceedings.

One of the problems concerning the "procedural framework for determining jurisdiction" (Proposal for a Regulation, 2012) is lack of information about the possible property in the other Member State or somewhere else. The author supposes that by analogy with the insolvency registers in order to achieve the Insolvency law purpose it should be necessary to include in the Regulation 2015/848 a provision ensuring that Land register offices or similar institutions in all Member states interconnect in one register that would be available to the insolvency administrators.

\section{References}

Bankruptcy Act of the Republic of Estonia (2003), [Accessed 10.03.2016]. Available from internet: https://www.riigiteataja.ee/en/eli/511072014018/consolide

Council Regulation (EC) No 1346/2000 of 29 May 2000 on Insolvency proceedings. Published at Official Journal of the European Communities on 30.06.2000, L 160/1

Council Regulation (EU) No 2015/848 of 20 May 2015 on Insolvency proceedings. Published at Official Journal of the European Union on 05.06.2015, L 141/19

European Commission (12.12.2012). Proposal for a Regulation of the European Parliament and of the Council amending Council Regulation (EC) No 1346/2000 on insolvency proceedings. [Accessed 21.02.2016]. Available from internet: http://www.europarl.europa.eu/sides/getDoc.do?pubRef=-//EP//TEXT+REPORT+A7-2013$0481+0+\mathrm{DOC}+\mathrm{XML}+\mathrm{V} 0 / / \mathrm{EN}$

Dirix E., Sagaert V. (2006) Cross-border insolvency in Belgian Private International Law. John Wiley \& Sons, Ltd.

Fletcher I.F. (2005). Insolvency in Private International Law. National and International Approaches. Oxford University Press

Garner B.A. (2001) Black's Law Dictionary. Second Pocket Edition. West Group.

Haas J.J. (2004). Corporate Finance. Thomson West 
Insolvency Law of the Republic of Latvia (2010). Published at "Latvijas Vēstnesis", 124 (4316), 06.08.2010.

Jakubecki A. (2013) Opening of Insolvency Proceedings pursuant to Council Regulation (EC) No 1346/2000 of 29 May 2000 on Insolvency Proceedings. Comparative Law Review

Janger E.J. (2007) Universal Proceduralism. Brooklyn Journal of International Law

Ķirsons M. (17.11.2015). Elektroniskās izsoles sevi attaisnojušas. The publication at newspaper Dienas bizness. [Accessed 10.03.2016]. Available from internet: http://www.db.lv/citas-zinas/elektroniskas-izsoles-seviattaisnojusas-441404)

Klein W.A., Coffee J.C. (2004). Business Organization and Finance. Foundation Press, New York

Lowenfeld A.F. (2003). International Economic Law. Oxford University Press Inc., New York

Moss G., Fletcher I., Isaacs S. (2009). The EC Regulation on Insolvency Proceedings. A Commentary and Annotated Guide. 2nd ed. Oxford University Press

Saleniece D., Upenieks G. (2007). Cross-border Insolvency proceedings. Ministry of Justice of the Republic of Latvia

Stones K. (2015) Final Wording-Recast Regulation on Insolvency 2015/848 published today. [Accessed 09.03.2016]. Available from internet: http://blogs.lexisnexis.co.uk/randi/final-wording-recast-regulation-oninsolvency/

The Cabinet of Republic of Latvia 16.06.2015. "Rules of electronic auctions site" No 318. Published at "Latvijas Vēstnesis", 124 (5442), 30.06.2015.

Torremans P. (2002) Cross Border Insolvencies in EU, English and Belgian Law. Kluwer Law International, The Hague, London, New York

Verweij A., Wessels B. (2010). Comparative and International Insolvency Law. Central Themes and Thoughts, INSOL Europe

Viimsalu S. (2011). The meaning and functioning of secondary insolvency proceedings: The concept of secondary insolvency proceedings as an exceptional phenomenon. LAP LAMBERT Academic Publishing

Virgós M., Garcimartín F. (2004). The European Insolvency Regulation: Law and Practice. 1st Edition. Kluwer Law International

Wessels B. (2006) International Insolvency Law, Kluwer

Wessels B., Omar P. (2009) Crossing (Dutch) Borders in Insolvency. INSOL Europe

Wessels B. (2012). International Insolvency Law. Kluwer, a Wolters Kluwer business 